\title{
Examination on Budgetary Control
}

\author{
R. Ramamoorthy, Gowtham Aasirvad Kumar, Magdalene Peter
}

\begin{abstract}
Arranging incorporates the establishment of predestined goals, the itemizing of genuine execution results and evaluation of execution with respect to the destined targets. Budgetary control structures are comprehensive and have been seen as an essential contraption for cash related orchestrating. The inspiration driving budgetary control is to give a figure of livelihoods and utilizations this is practiced through structure a model of how our business may perform fiscally if certain philosophies, events and plans are finished. Most firms use spending control as the fundamental techniques for corporate inside controls, it gives an extensive the board stage to beneficial and effective assignment of advantages. Budgetary controls enable the supervisory group to make courses of action for the future through executing those plans and watching activities to see whether they fit in with the game plan, suitable use of budgetary control is a huge affirmation for the feasible use of spending plan in the affiliation. This assessment broke down the budgetary control in Non-Governmental Organizations and its effects on their display. The investigation target masses included 7,127 Non-Governmental Organizations[1],[3],[5]
\end{abstract}

Keywords : Budget,framework,sysytems

\section{INTRODUCTION}

A spending farthest point is a budgetary game plan for the future concerning the livelihoods and costs of a business. Nevertheless, a spending point of confinement is about essentially more than basically cash related numbers. Budgetary control is the methodology by which financial control is polished inside an affiliation. [2 ],[4],[6]

Spending plans for cash/salary and use are set up early and a short time later stood out from genuine execution with develop any changes. Chairmen are accountable for controllable costs inside their money related breaking points and are required to cause restorative move if the horrible variances to develop and they are seen as outrageous. [7],[9] ,[11]

Revised Manuscript Received on July 22, 2019.

R.Ramamoorthy, Department of MBA, Bharath Institute of Higher Education and Research, Tamilnadu, India. Email: ramamoorthy0071@gmail.com

Gowtham Aasirvad Kumar, Department of MBA, Bharath Institute of Higher Education and Research, Tamilnadu, India. Email: kgowthamaashirwad123@gmail.com

Magdalene Peter, Department of MBA, Bharath Institute of Higher Education and Research, Tamilnadu, India. Email: magdalene.bsb@gmail.com

\section{OBJECTIVES}

\section{A. PRIMARY OBJECTIVE}

To study on Budget and Budgetary Control at Fastronic Teleservices Private Limited, Mylapore, Chennai.

B. SECONDARY OBJECTIVE

To examination similar investigation of both past year and current year execution of the association. [8],[ 10] ,[12]

- To think about the previous year and current year execution of the association with the assistance of accounting report and salary proclamation.

To break down the proportion in the association

\section{SCOPE OF THE STUDY}

- The present investigation is kept to the investigation of frameworks and systems in assessment of budgetary control procedures that are been utilized in FASTRONIC TELESERVICES PRIVATE LIMITED.

- The investigation directed on spending plan and budgetary control of FASTRONIC TELESERVICES PRIVATE LIMITED is spread the all money related territory of divisions like creation, deals, fund, and so forth,.

- Anyway spending plan and budgetary control bolster the top level administration to take an appropriate choice, in crafted by application.

\section{STATEMENT OF THE PROBLEM}

Numerous business firms perceive the need a created and far reaching budgetary control framework so as to limit spending differences, costs and augment productivity. Budgetary control is as pivotal as money itself and any burglary, squander, exorbitant use or stock out could prompt the business' lackluster showing. Fastronic teleservices private constrained has recognized that its presentation is impacted by budgetary control. This is prove by a budgetary shortfall of shillings $19.3 \mathrm{cr}$ in the time of 2011 fiscal reports. It is against this situation that has been picked enthusiasm for dissecting the impact of spending plan and budgetary controls on business execution. [13], [15] ,[ 17] 


\section{Examination on Budgetary Control}

\section{V.RESEARCH METHODOLOGY}

A.MEANING:

The procedure used to gather data and information to settle on business choices. The strategy may incorporate production inquire about, interviews, overviews and other research strategies and could incorporate both present and authentic data.

\section{B.PRIMARY DATA:}

It is additionally called as first given data the information is gathered through the perception in the association and by posing inquiries with the records and different people in the budgetary divisions. A section from these some data was gathered through the courses, which were held by FASTRONIC TELESERVICES PRIVATE LIMITED, CHENNAI. [14],[ 16], [18]

\section{C.SECONDARY DATA}

These auxiliary information is existing information which is gathered by others that is sources are money related diaries, yearly reports, utilization of web, standard reference course readings and information given by the FASTRONIC TELESERVICES PRIVATE LIMITED, CHENNAI. [19],[21],[23]

D.PERIOD OF THE STUDY

The research took three months for the studying the budget and budgetary control for the past and future operations of an organization. [20],[22], [24]

\section{ANALYSIS AND INTERPRETATION}

All the data were analyzed and interpretations were made by using various financial tools and techniques.

TOOLS AND TECHNIQUES USED:

1. RATIO ANALYSIS

2. COMPARATIVE STATEMENT

DATA ANALYSIS AND INTERPRETATION

RATIO ANALYSIS

\section{CURRENT RATIO:}

\begin{tabular}{|l|c|c|c|}
\hline YEAR & CURRENT ASSETS & CURRENT LIABILITIES & TOTAL \\
\hline $2013-2014$ & 10432016.38 & 3109422.62 & 3.36 \\
\hline $2012-2013$ & 13796193.00 & 2150663.00 & 6.41 \\
\hline $2011-2012$ & 7743742.00 & 2435572.00 & 3.18 \\
\hline
\end{tabular}

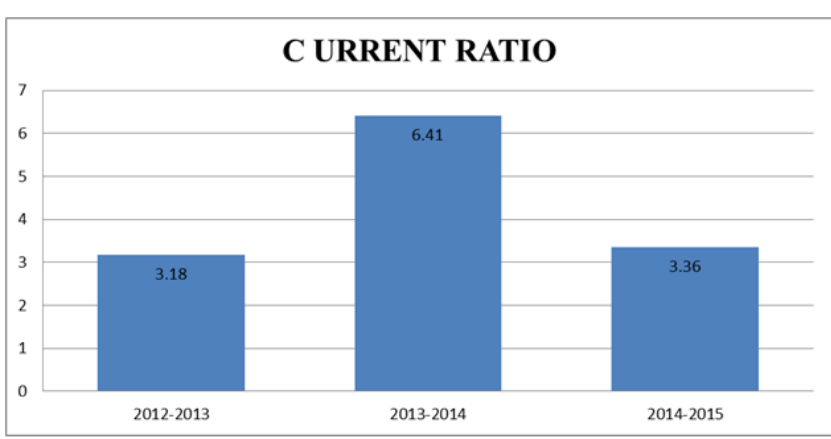

\section{INTERPRETATION:}

As per the above table and chart the current ratio of the organization in 2012-2013 is 3.18 times, in 2013-2014 the percentage is high by 6.41times and in 2014-2015 became reduced by 3.36 times. [26],[28],[30]

\section{CASH POSITION RATIO}
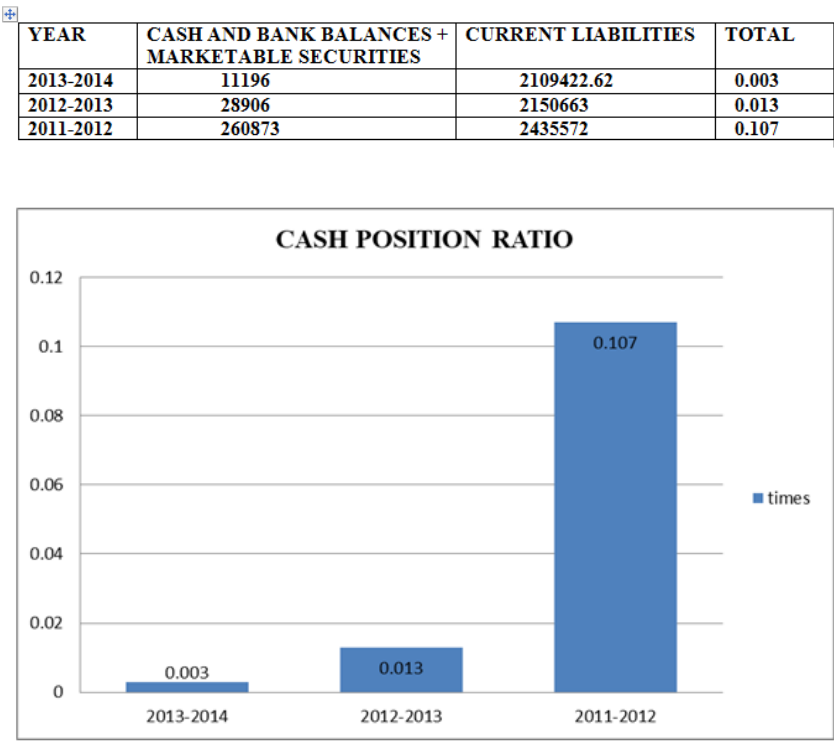

\section{INTERPRETATION}

As per the above table and chart the cash position ratio of an organization in the year 2012-2013 is 0.107 times high than the other two years of 2013-2014 is 0.013times and in the year 2014-2015 is 0.003 times less than the previous year. [25],[27],[29]

\section{PROPRIETARY RATIO}

\begin{tabular}{|c|c|c|c|}
\hline YEAR & SHAREHOLDER'S FUND & TOTAL TANGIBLE ASSETS & TOTAL \\
\hline 2013-2014 & 100000 & 72298 & Rs. 1.383 \\
\hline 2012-2013 & 100000 & 98242 & Rs. 1.018 \\
\hline 2011-2012 & 100000 & 83455 & Rs. 1.198 \\
\hline
\end{tabular}

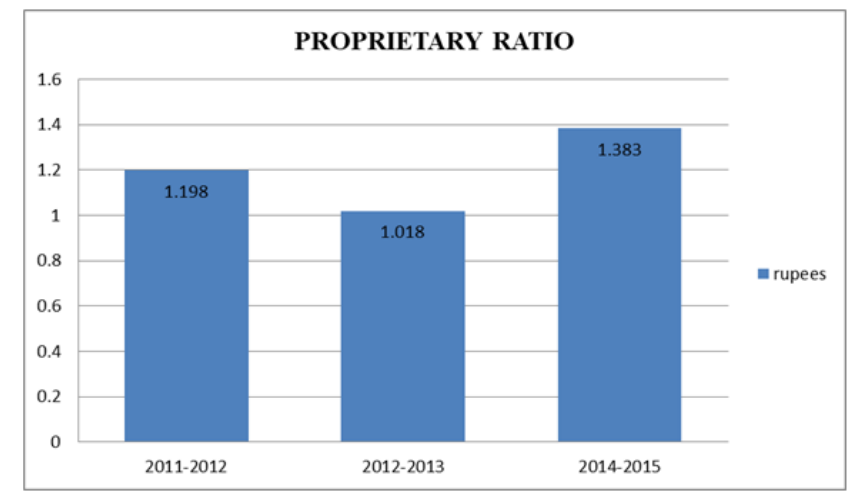

\section{INTERPRETATION}

As per the table and chart the proprietary fund of the organization in the year 2012-2013 is Rs. 1.198 , in the year 2013-2014 is Rs. 1.018 and in the year 2014-2015 is Rs. 1.383 during the financial period. 


\section{FIXED ASSETS RATIO}

\begin{tabular}{|l|l|l|l|}
\hline YEAR & FIXED ASSETS & CAPITAL EMPLOYED & RATIO \\
\hline $2013-2014$ & 72298 & 100000 & 0.72 \\
\hline $2012-2013$ & 98242 & 100000 & 0.98 \\
\hline $2011-2012$ & $\mathbf{8 3 4 5 5}$ & 100000 & 0.83 \\
\hline
\end{tabular}

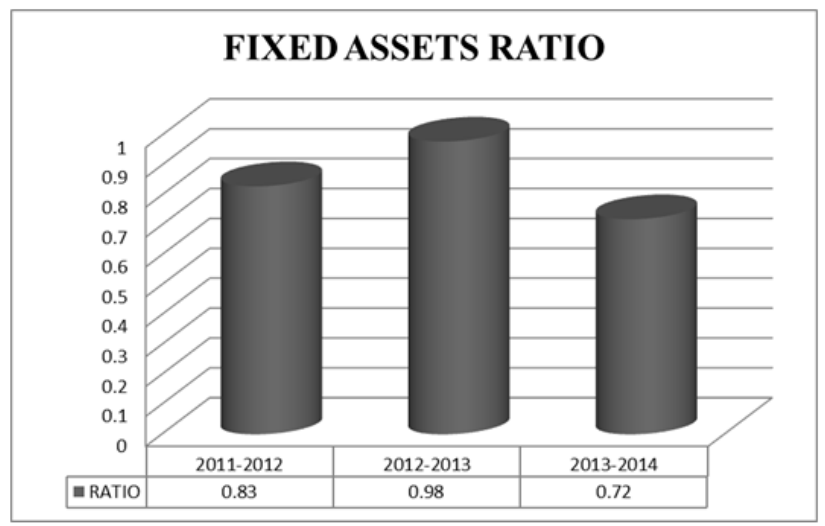

\section{INTERPRETATION}

As per the table and chart the fixed asset ratio should not be more than las per the note in the year 2011-2012 is $0.83,2012-2013$ is 0.98 and in 2013-2014 is 0.72 the capital employed are invested in fixed assets which means a reasonable portion of it are used to finance the fixed portion of working capital. [31],[33],[32]

\section{COMPARATIVE INCOME STATEMENT FOR THE}

YEAR 2012-2013

\begin{tabular}{|l|c|c|c|c|}
\hline PARTICULARS & $\begin{array}{c}2012 \\
(\mathrm{Rs.})\end{array}$ & $\begin{array}{c}2013 \\
(\mathrm{Rs.})\end{array}$ & AMOUNT & PERCENTAGE \\
\hline Income & 26846963 & 19656143 & 7190820 & $27 \%$ \\
\hline Other income & 1755 & 12680 & 10925 & $62 \%$ \\
\hline Total revenue(A) & 26848718 & 19668823 & 7179895 & $27 \%$ \\
\hline EXPENSES & & & & \\
\hline Purchase of stock & 3110620 & - & 3110620 & $100 \%$ \\
\hline $\begin{array}{l}\text { Employee benefit } \\
\text { expense }\end{array}$ & 9456015 & 9909161 & 453146 & $5 \%$ \\
\hline Financial cost & 561 & 1437 & 876 & $1.56 \%$ \\
\hline $\begin{array}{l}\text { Depreciation and } \\
\text { amortization cost }\end{array}$ & 8192 & 24213 & 16021 & $1.96 \%$ \\
\hline Other expenses & 14765477 & 8845562 & 5919915 & $40 \%$ \\
\hline Total expenses (B) & 27340865 & 18780373 & 8560492 & $31.3 \%$ \\
\hline $\begin{array}{l}\text { Total income for } \\
\text { the year 2012-2013 }\end{array}$ & 492147 & 885450 & 396303 & $81 \%$ \\
\hline
\end{tabular}

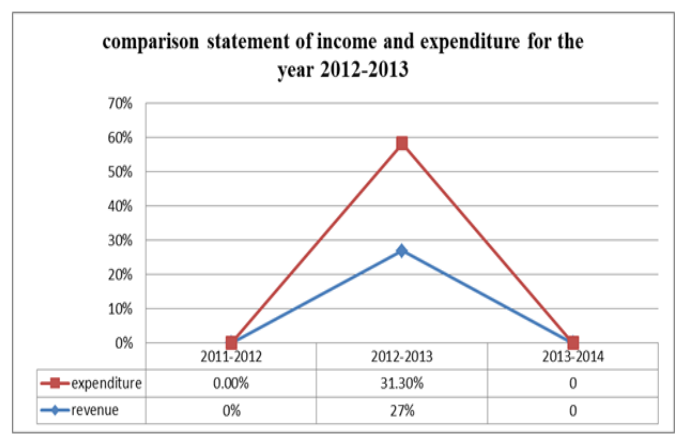

\section{INTERPRETATION}

As per the chart and table for the 2012 - 2013 expenditure is of high by $31.3 \%$ and income is $27 \%$ less than the expenditure. They have to decrease the unwanted expense and increase the income for the following years.

\section{COMPARATIVE INCOME STATEMENT FOR THE}

\section{YEAR 2013-2014}

\begin{tabular}{|c|c|c|c|c|}
\hline PARTICULARS & $\begin{array}{l}2013 \\
\text { (rs.) }\end{array}$ & $\begin{array}{l}2014 \\
\text { (rs.) }\end{array}$ & AMOUNT & PERCENTAGE \\
\hline Income & 19656143 & 13201350 & 6454793 & $33 \%$ \\
\hline Other income & 12680 & - & 12680 & $100 \%$ \\
\hline Total income (A) & 19668823 & 13201350 & 6467473 & $32.8 \%$ \\
\hline \multicolumn{5}{|l|}{ EXPENSES } \\
\hline \multicolumn{5}{|c|}{\begin{tabular}{|l|l|} 
Purchase of stock & \\
\end{tabular}} \\
\hline $\begin{array}{l}\text { Employee benefit } \\
\text { expenses }\end{array}$ & 9909161 & 4950650 & 4958511 & $50 \%$ \\
\hline Financial cost & 1437 & 662.36 & 774.64 & $54 \%$ \\
\hline $\begin{array}{l}\text { Depreciation } \\
\text { amortisation }\end{array}$ & 25944 & 25944 & 0 & 0 \\
\hline Other expenses & 8845562 & 7223129.91 & 1622432.09 & $18.34 \%$ \\
\hline Total expenses (B ) & 18782104 & 12200386.27 & 6581717.73 & $55 \%$ \\
\hline $\begin{array}{l}\text { Total income for the } \\
\text { year 2013-2014 }\end{array}$ & 886719 & 1000963.73 & 114244.73 & $12.9 \%$ \\
\hline
\end{tabular}

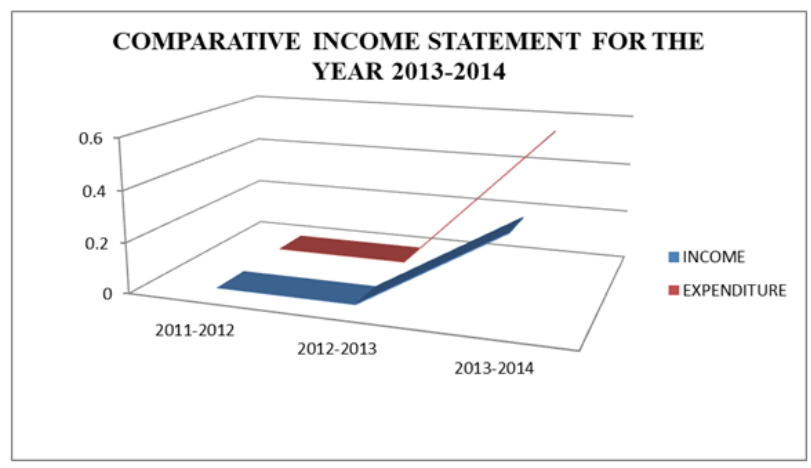

VII. RESULTS

The analysis of current ratio during the following years

- 2011-2012 - 3.18 times

- 2012-2013-6.41 times

- 2013-2014 - 3.36 times

The analysis of cash position ratio during the following years

- 2011-2012-0.107 times

- 2012-2013 - 0.013 times

- 2013-2014-0.003 times

The analysis of proprietary ratio during the following years

- 2011-2012 - rs.1.198

- 2012-2013-rs.1.018

- 2013-2014 - rs. 1.383

The analysis of fixed assets ratio during the following years

- 2011- $2012-0.83$

- 2012- 2013-0.98

- 2013-2014-0.72

The computation of income and expenditure for the year $2012-2013$ is $27 \%$ and $31.3 \%$ which makes profit to the concern.

The computation of income and expenditure for the year $2013-2014$ is $32.8 \%$ and $55 \%$ which makes profit to the concern.

\section{DISCUSSION}

- Based on the current ratio the liabilities are below the current assets and they have to look up on the capital funding of their project during the financial year.

- During the cash position is the liquid handled by the financier of the

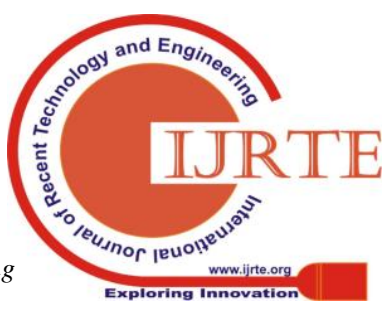




\section{Examination on Budgetary Control}

concern and he should to the workers when they are need of it.

- During the proprietary fund is also provided averagely for the service rendered by him/ her in the organization.

- The fixed assets ratio the capital employed used for financing fixed assets. The ratio should not be more than 1 due to the part of working capital that is also been used for financing the investment of capital in the business.

- The increase or decrease of each item should be shown as percentage of the first year value i.e. 2012-2013. Thus the first year is deemed as 'base year' for the calculation of percentage.

- The increase or decrease of each item should be shown as percentage of the first year value i.e. 2013-2014. Thus the first year is deemed as 'base year' for the calculation of percentage.

\section{CONCLUSION}

The study on overall production of a privately owned organization was aimed at gaining the practical knowledge regarding the production of the concern at a period of measures is of 3 years with reference to Fastronic Teleservices Private Limited, Chennai. The study is completed successfully within the limited period of time with help, guidance and co-operation of the officials. Some of the suggestions have been accepted and appreciated for implementation and some are implemented.

\section{REFERENCES}

1. G BharthVajan R., Ramachandran S.,Psychographic dimensions of training,2016,International Journal of Pharmacy and Technology,V-8,I-4,P-23727-23729

2. Balakrishnan P., Bharthvajan R.,A study on human resource planning in hospitals in Chennai City,2014,International Journal of Applied Engineering Research,V-9,I-22,P-7503-7507

3. Priyadarsini P., Bharthvajan R.,Role of emotional intelligence training programme in reducing the stress of the nurses,2014,International Journal of Applied Engineering Research,V-9,I-22,P-7411-7421

4. Kerinab Beenu G., Bharthvajan R.,Empirical analysis on the cosmetic buying behavior of young women in South India,2014,International Journal of Applied Engineering Research,V-9,I-22,P-7361-7366

5. Balakrishnan P., Bharthvajan R.,Whistling in the wind,2014,International Journal of Applied Engineering Research,V-9,I-22,P-7586-7593

6. Krishnan B., Peter M.,Health hazards of Indian Bpo employee-an alarming issue,2014,International Journal of Applied Engineering Research,V-9,I-22,P-7336-7341

7. Kerinab Beenu G.H., Peter M.,Role of insurance in economic development,2014,International Journal of Applied Engineering Research,V-9,I-22,P-7532-7539

8. Balakrishnan P., Peter M., Priyadarsini P.,Efficiency of safety measures for wellbeing of employees in manufacturing industry,2014,International Journal of Applied Engineering Research,V-9,I-22,P-7376-7382

9. Anbarasi M., Praveen Kumar S.,Online sales promotions of herbal products and its effectiveness towards tanisha.com,2019,Indian Journal of Public Health Research and Development,V-10,I-1,P-195-200

10. Anbarasi M., Praveen Kumar S., Various online marketing and promotions strategies to improve the validation towards the organic products in the pharmaceutical sectors,2019,Indian Journal of Public Health Research and Development,V-10,I-1,P-263-269

11. Loganathan R., Praveen Kumar S.,Grievance handling a key factor for solving issues of employees in an organization,2014,International Journal of Applied Engineering Research,V-9,I-22,P-7483-7491

12. Loganathan R., Praveen Kumar S.,Study on preference of private label brands in super and Hypermarkets,2014,International Journal of Applied Engineering Research,V-9,I-22,P-7327-7335
13. Smitha M., Praveen Kumar S.,Understanding stress and its managementamong the nurses in Chennai city,2014,International Journal of Applied Engineering Research,V-9,I-22,P-7560-7565

14. Kerinab Beenu G.H., Praveen Kumar S.,A study on the investment behavior of Chennai investors in mutual fund schemes,2014,International Journal of Applied Engineering Research,V-9,I-22,P-7520-7525

15. Loganathan R., Praveen Kumar S.,Retention strategies key for organizational productivity,2014,International Journal of Applied Engineering Research,V-9,I-22,P-7443-7447

16. Pavithra J., Ganesan M., Brindha G.,State wise analysis of microfinance sector in India,2016,International Journal of Pharmacy and Technology,V-8,I-4,P-23417-23432

17. Pavithra J., Ganesan M.,A comparative study on microfinance in India and abroad,2016,International Journal of Applied Business and Economic Research,V-14,I-8,P-5471-5476

18. Pavithra J., Ganesan M.,A study on awareness and impact of micro-financial schemes,2016,International Journal of Applied Business and Economic Research,V-14,I-8,P-5449-5460

19. Senthilmurugan P., Pavithra J.,Consumer preference towards organised retailing with reference to Big Bazaar,2014,International Journal of Applied Engineering Research,V-9,I-22,P-7469-7475

20. Senthilmurugan P., Pavithra J.,Implication of social media marketing in growing healthcare industry,2014,International Journal of Applied Engineering Research,V-9,I-22,P-7448-7456

21. Loganathan R., Pavithra J.,Consumer perception towards private label brand over other brands in super markets and hypermarkets,2014,International Journal of Applied Engineering Research,V-9,I-22,P-7355-7360

22. Kerinab Beenu G., Pavithra J.,Tradeâ€"off between liquidity and profitability in logistics industry,2014,International Journal of Applied Engineering Research,V-9,I-22,P-7398-7401

23. Kerinab Beenu G., Pavithra J.,A study on the prospective consumerâ€ $\mathbf{T M}_{\mathrm{S}}$ perception towards utility cars in Chennai city,2014,International Journal of Applied Engineering Research,V-9,I-22,P-7526-7531

24. Pavithra J., Dilli Babu P., Ambuli T.V.,A study on budgetary control at Maruti Service Masters, Chennai,2014,International Journal of Applied Business and Economic Research,V-12,I-2,P-151-161

25. Pavithra J., Dilli Babu P., Ambuli T.V.,A study on customer satisfaction of retro Garments Pvt Ltd, Chennai,2014,International Journal of Applied Business and Economic Research,V-12,I-2,P-381-391

26. Kerinab Beenu G.H., Pavithra J., Senthilmurugan P.,A study on the influence of promotional activities for TATA ARIA among consumers in Chennai,2014,International Journal of Applied Engineering Research,V-9,I-22,P-7572-7578

27. Vijayaragavan S.P.,An investigative expert that's general FBG sensors,International Journal of Mechanical Engineering and Technology,V-8,I-8,PP-1500-1505,Y-2017

28. Vijayaragavan S.P.,Equalization routing protocol for Wi-Fi sensor strategy,International Journal of Mechanical Engineering and Technology,V-8,I-8,PP-1662-1666,Y-2017

29. Karthik B., Kiran Kumar T.V.U., Vijayaragavan P., Bharath Kumaran

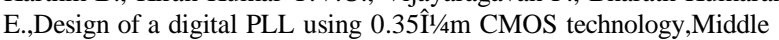
East Journal of Scientific Research,V-18,I-12,PP-1803-1806,Y-2013

30. Kanniga E., Selvaramarathnam K., Sundararajan M.,Kandigital bike operating system,Middle - East Journal of Scientific Research,V

31. Jasmin M., Vigneshwaran T., Beulah Hemalatha S.,Design of power aware on chip embedded memory based FSM encoding in FPGA,International Journal of Applied Engineering Research,V-10,I-2,PP-4487-4496,Y-2015

32. Jasmin M.,Optimization techniques for low power VLSI circuits,Middle East Journal of Scientific Research,V-20,I-9,PP-1082-1087,Y-2014

33. Jasmin M., Vigneswaran T.,Fuzzy controller for error control of on - Chip communication,2017 International Conference on Algorithms, Methodology, Models and Applications in Emerging Technologies, ICAMMAET 2017,V-2017-January,I-,PP-1-5,Y-2017 


\section{AUTHORS PROFILE}

R.Ramamoorthy Assistant Professor ,Department of MBA, Bharath Institute of Higher Education and Research, Tamilnadu, India

Gowtham Aasirvad Kumar Assistant Professor ,Department of MBA, Bharath Institute of Higher Education and Research, Tamilnadu, India

Magdalene peter Assistant Professor ,Department of MBA, Bharath Institute of Higher Education and Research, Tamilnadu, India 